\title{
The stimulating role of the products of oxygen biotransformation by organotrophic bacteria in metal corrosion: A review
}

\author{
A.A. Kalinina,* T.N. Sokolova and E.P. Komova \\ Federal state budgetary higher education institution "R.E. Alexeev Nizhny Novgorod state \\ technical university”, ul. K. Minina, 603950 Nizhny Novgorod, Russian Federation \\ *E-mail: 777aleksa777_87@mail.ru
}

\begin{abstract}
The review discusses the role of oxygen biotransformation products - hydrogen peroxide and ammonia formed during the vital activity of microorganisms - in the initiation of biological corrosion. The quantitative characteristics of the content of hydrogen peroxide, one of the main corrosive components in the exudate, are given. Using scanning electron microscopy, it has been shown that the effect of organotrophic bacteria on steel samples begins with the formation of a biofilm on the surface, as visualized by the appearance of a liquid-drop exudate with $\mathrm{pH}>7$ on its surface, especially in the edge regions. It has been shown that the biological corrosion of low-carbon steel is of mixed type, i.e., pitting-ulcer corrosion combined with stress corrosion cracking and intergranular corrosion.
\end{abstract}

Keywords: biological corrosion, organotrophic bacteria, hydrogen peroxide, ammonia.

Received: November 2, 2020. Published: November 24, 2020

doi: $\underline{10.17675 / 2305-6894-2020-9-4-17}$

\section{Introduction}

The problem of the corrosion damage of metals operated in humid and/or aqueous environments is faced in many industries where metals, products and structures based on them are used. The estimated direct and indirect losses from biocorrosion around the world amount to $\$ 1.8$ trillion per year (3-4\% of the gross domestic product in industrialized countries) [1].

The first reports on the stimulating role of microorganisms in metal corrosion appeared about 80 years ago and dealt with the effect of sulfate-reducing bacteria on a metal, especially in the environments used in the production, treatment and storage of oil products $[2,3]$. A significant role in the creation of the new direction in corrosion studies belongs to the problems of operation of military equipment and equipment in warm and humid climates where the rate of metal destruction exceed the expected rates by several orders of magnitude $\left(10^{3}-10^{4}\right)[4,5]$.

By the middle of the past century, the concept of biocorrosion, or more strictly, microbiologically induced corrosion (MIC), was shaped. It was defined as the deterioration of the metal properties caused by corrosive products of the microorganisms' vital activity [6]. 
Several groups of biogenic corrosive factors can be distinguished when one analyzes the current state of MIC. Preference in each of these groups is given to a certain type of compounds that create an environment that is corrosive toward a metal.

The first group of biogenic corrosive factors comprises sulfur compounds, including sulfuric acid. The availability and physicochemical properties of sulfur make it an element that is widely used in biological systems.

It should be noted that sulfate reducers were historically regarded as the key initiators of MIC. It is the unusually large corrosion damage to pipelines operating in the absence of corrosive agents in mineralized media and soil electrolytes that prompted the search for additional factors that stimulate corrosion. Subsequently, it was found that sulfate-reducing bacteria present in the soil were the cause of abnormally high corrosivity [7-10]. At present, sulfate reducers are still the main objects of biocorrosion studies.

The second group of corrosive metabolites includes nitrogen compounds. Corrosive compounds are biotransformed by the community of nitroso- and nitrobacteria from ammonia. The latter is released by bacteria into the environment from the excess nitrogen that is formed in cells during the breakdown of nitrogen-containing food sources $[8,9,11]$.

The third group of corrosive metabolites is associated with iron bacteria. In particular, the vital activity of these bacteria causes the microbial corrosion of water pipes: the abundant growth of iron bacteria leads to the formation of dark brown barnacles or cavities, often large ones, on the inner wall of a pipe $[8,9,12,13]$, which results in the blockage of narrow pipes or water pollution ("red water").

At the same time, organotrophic bacteria are widely represented in the nature. However, at present there is no clear understanding regarding the mechanism of their stimulating effect on metals. Some researchers believe that organic acids may play the major role. As a rule, this can take place in the food production where various types of fermentation are used (lactic acid, propionic acid, acetic acid, etc.). For example, it has been proven that the corrosion of steel in beet sugar production involves lactic acid bacteria that produce lactic acid [14-16].

The role of exoenzymes is being actively discussed. It is known that organotrophic bacteria can use almost any organic compounds as the food source. However, many of them can do so only after extracellular biotransformation into readily digestible forms under the action of enzymes, usually of the oxidoreductase or hydrolase classes, secreted by them. In simplified form, the initial stage of redox destruction of organic compounds, for example, oil components, can be represented as follows [17-19]:

$$
\mathrm{RH}+\mathrm{O}_{2}+\mathrm{H}_{2} \mathrm{O} \stackrel{\text { oxidoreductase }}{\longrightarrow} \mathrm{ROH}+\mathrm{H}_{2} \mathrm{O}_{2}
$$

$\mathrm{H}_{2} \mathrm{O}_{2}$ that is formed is corrosive and can change the chemical characteristics of the passivated layer, for example, on stainless steel [20].

In some works, the action of $\mathrm{H}_{2} \mathrm{O}_{2}$ on the metal surface is considered in combination with the catalase enzyme, which, by decomposing hydrogen peroxide to give oxygen, enhances the electrochemical component of the corrosion process [21]. 
However, it should be noted that in most cases, studies on the corrosive activity of organotrophic bacteria were carried out in liquid media, which most often simulated seawater or soil water sources $[22,23]$. The effect of this type of bacteria on the surface of metals without participation of a liquid external environment is currently being studied only in the context of the formation of biofilms, their properties, and chemical composition [2426]. The conclusions on the relationship between the biofilms of organotrophic bacteria and the corrosion damage of metals are sporadic, as is the information on the chemical nature of the stimulating factors in these cases.

Because of this, in this review, we analyze works in which a comprehensive approach to the study of processes occurring upon direct contact of metals with organotrophic bacteria cultivated on a dense nutrient medium under conditions optimal for their vital activity was suggested.

It was assumed in some studies published in the past decade that the products of intracellular oxygen biotransformation can be a factor stimulating corrosion. For the first time, conclusions of this kind were made in [27] in a study of the effect of microscopic fungi on the surface of aluminum and its alloys. The following phenomena were observed upon exposure of metals on a seven-day lawn of microscopic fungi: after 1-3 days, a liquiddroplet exudate with $\mathrm{pH}>7$ (7.5-12) appeared on the surface, but the ions of the metal under study were not detected in it. Subsequently, the exudate, through the gelation stage, passed into a loose solid state, in which corrosion products and organic compounds - products of the vital activity of microorganisms - were identified in approximately equal amounts. A scheme of the corrosion stimulation of aluminum and its alloys was suggested, with involvement of the superoxide anion $\mathrm{O}_{2}^{-}$as a side product of one-electron transfer in the electron transport chain of microscopic fungi [27].

In the same work, based on the absence of an exudate on the surfaces of aluminum and its alloys, the wrong conclusion was made that $\mathrm{O}_{2}^{-}$could not be involved in the corrosion stimulation by organotrophic bacteria [27].

The ability of microscopic fungi to secrete the superoxide anion into the pericellular environment was confirmed using a non-selective indicator, nitro blue tetrazolium chloride, under control by the superoxide dismutase enzyme that has absolute specificity for $\mathrm{O}_{2}^{-}$[28]. It was found later that the time of exudate appearance on the surface of the metal, its amount, and $\mathrm{pH}$ depend both on the nature of the metal and on the type of the microorganism. In particular, an exudate was also detected on the surface of some metals exposed to organotrophic bacteria [29].

It was found [29] that a basic exudate ( $\mathrm{pH}$ 10-12) was formed most intensely on a zinc surface. The use of this metal as the research object initiated a new round of studies on corrosion in the presence of organotrophic bacteria and led to the conclusion about the generality of the mechanism of corrosion stimulation by both microscopic fungi and bacteria, based on the participation of oxygen biotransformation products and, in some cases, protein nitrogen. 
It has been shown [29] that the action of organotrophic bacteria on a metal surface (zinc, galvanized steel, St3 steel) is accompanied by the same visually observed effects that appear in a certain sequence, like in the presence of microscopic fungi.

In 1-3 days from the beginning of metal exposure on a dense nutrient medium inoculated with bacteria, a liquid-droplet exudate with $\mathrm{pH} \geq 7$ is formed on some surface areas. This effect is observed most clearly where bacteria affect the surface of zinc or galvanized steel (Figure 1a and Figure 2a), and to a smaller extent, on the surface of steel (Figure 3).

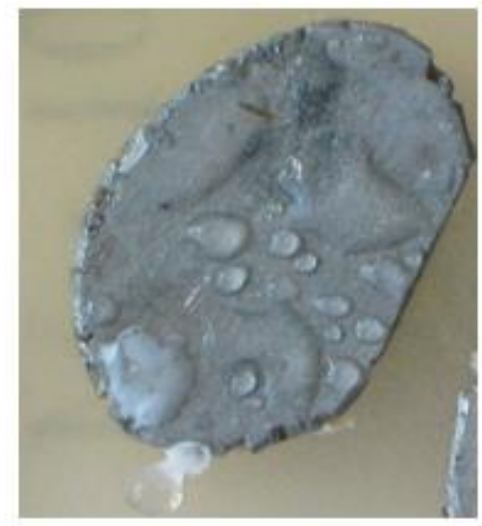

$a$

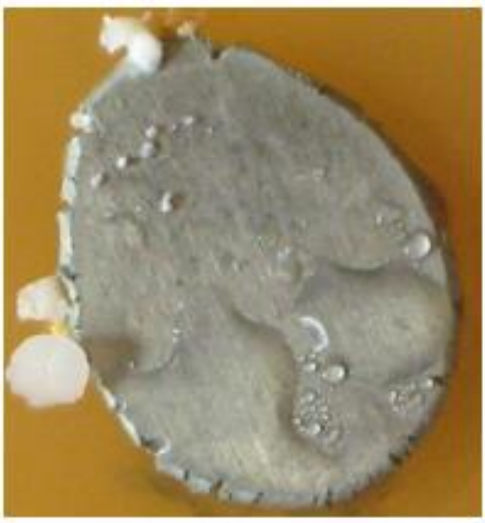

$b$

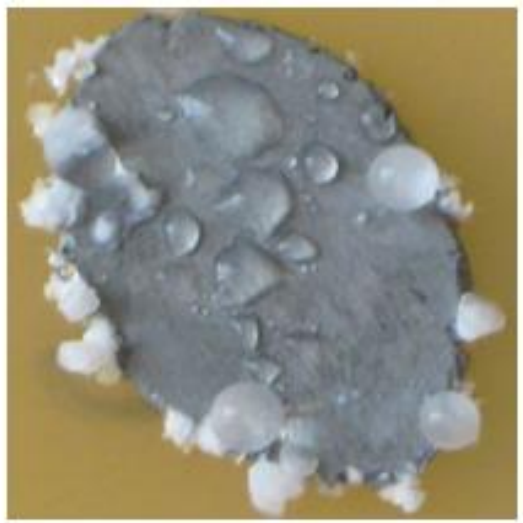

$c$

Figure 1. Micrographs of the surface of zinc samples exposed to Staphylococcus aureus bacteria. Time after the exposure start: $a-10$ days; $b-15$ days; $c-30$ days.

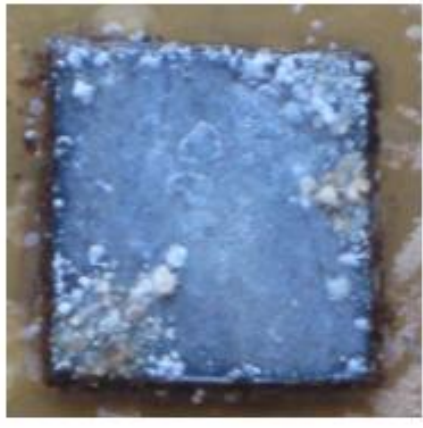

$a$

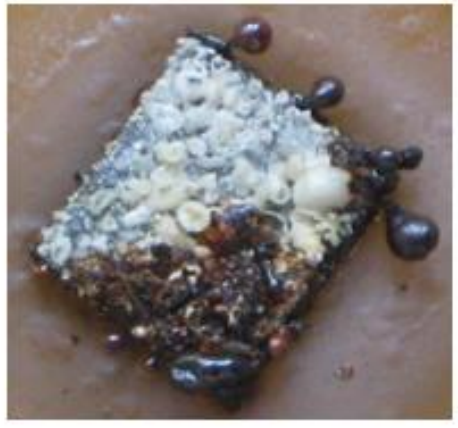

$b$

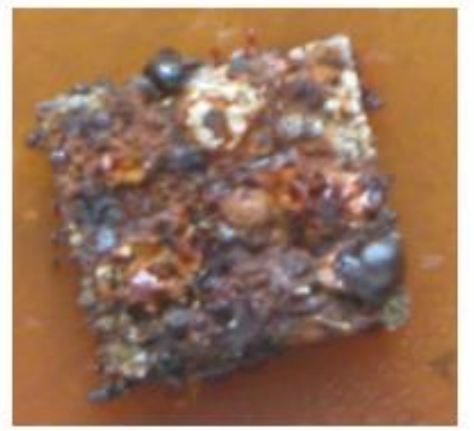

$c$

Figure 2. Micrographs of the surface of galvanized steel samples exposed to Pseudomonas aeruginos $a$ bacteria. Time after the exposure start: $a-10$ days; $b-30$ days; $c-65$ days.

With time (7-10 days on average), the exudate turns into a gel-like state, followed by solidification after $c a$. 30-50 days (Figure $1 b-c$, Figure $2 b-c$ ) from the beginning of exposure. 
It was assumed [27-29] that, to identify the mechanism of the stimulating effect of organotrophic bacteria on the metal, the period when the first signs of an exudate appear on the surface is informative (Figure $1 a, 2 a, 3$ ).

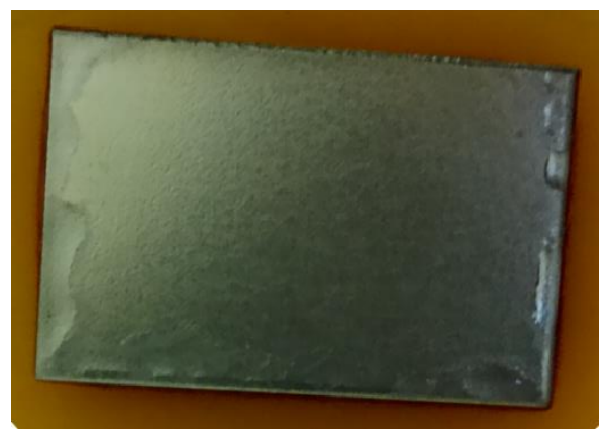

Figure 3. Change in the state of steel surface in 2 days of exposure to Pseudomonas aeruginosa bacteria.

It was found by microstructural analysis that the visualization of bacterial effects based on the liquid droplet exudate is associated with the beginning of the metal surface colonization [30]. As one can see from Figure $4 a-c$, active colonization of the surface begins on exposure of steel surface to Pseudomonas aeruginosa bacteria under optimal conditions of their vital activity: individual bacterial cells (Figure $4 a$ ) and in some areas bacterial colonies are attached (Figure $4 b$ ), while a morphology of the biofilm being formed is observable along the metal edges (Figure 4).

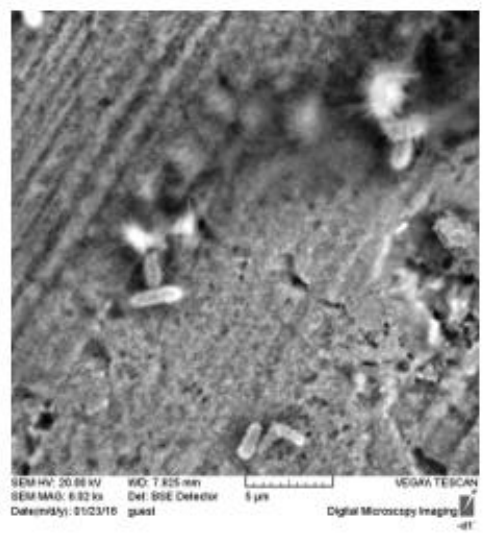

$a$

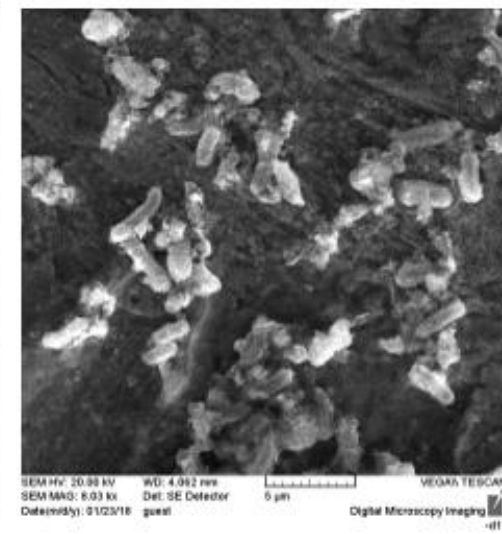

$b$

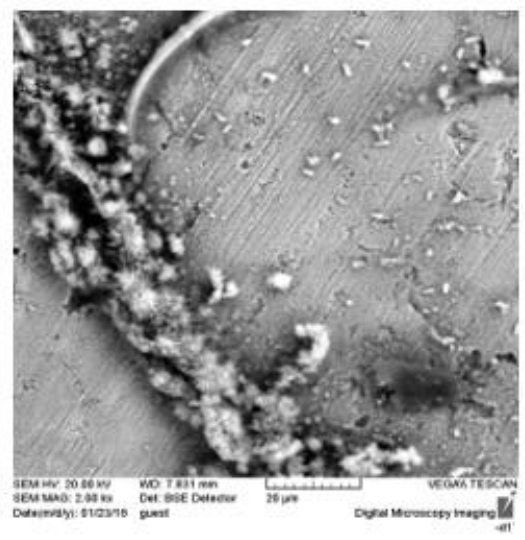

$c$

Figure 4. Micrographs of steel surface after 2 days of exposure upon exposure to

Pseudomonas aeruginosa bacteria: $a$ - separate bacterial cells on the metal surface; $b-$ bacterial colonies; $c-$ a biofilm fragment [31].

The colonization of the surface of zinc and galvanized steel on exposure to Bacillus subtilis bacteria occurs more vigorously on days 2-3 from the beginning of exposure, whereas separate bacteria are no longer detectable. As one can see from Figure 5, after three 
days, a biofilm is formed as bacterial communities and an exopolysaccharide framework as needle-like formations in the micrographs (Figure 5a) [32].

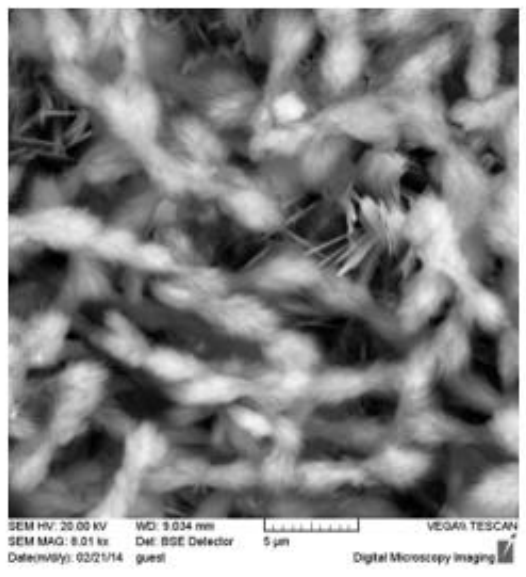

$a$

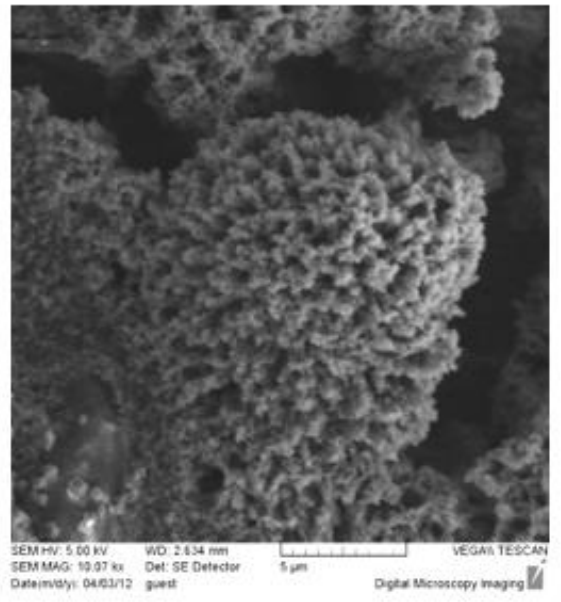

$b$

Figure 5. Micrographs of zinc surface after 3 days of exposure to Bacillus subtilis bacteria (a) and galvanized low-carbon steel (galvanic coating, coating thickness 15-20 $\mu \mathrm{m}$ ) after 5 days of exposure to Escherichia coli bacteria (b) [33].

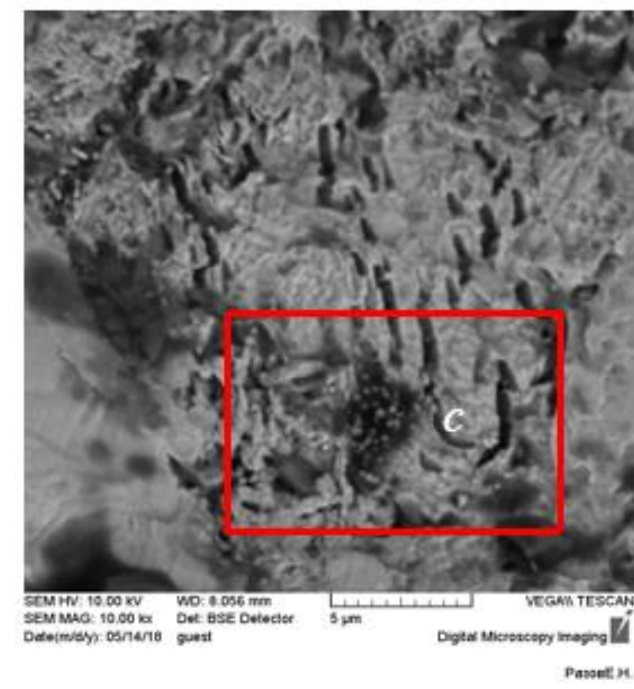

$a$

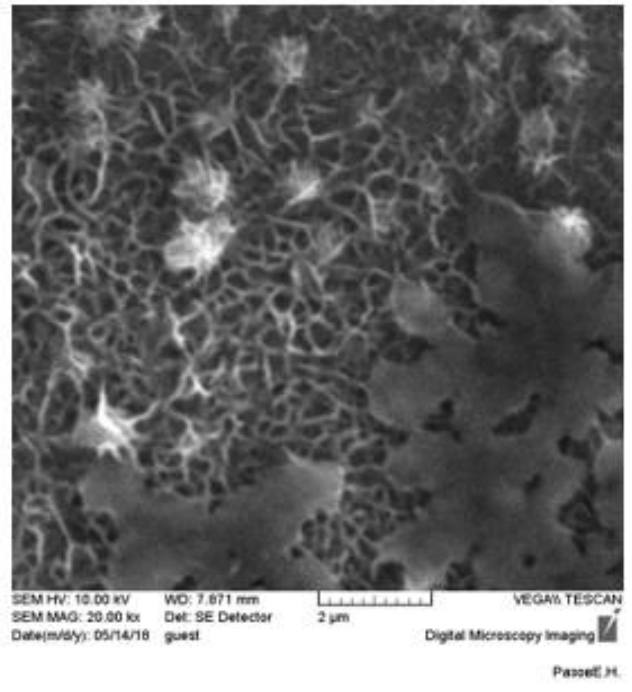

$b$

Figure 6. Micrographs of a steel surface after 35 days of exposure to Pseudomonas aeruginosa bacteria (magnification: $a-\times 10,000 ; b-\times 20,000$ ).

Upon exposure of galvanized steel to Escherichia coli bacteria, a biofilm was formed over almost the entire surface in 5 days after the beginning of exposure, as demonstrated in Figure $5 b$, as a spongy structure in which the morphological features of individual bacteria and their communities were no longer distinguishable [33]. 
It should be noted that the effect of organotrophic bacteria on a metal continues for a long time, since the bulk phase of the metal, more precisely, the metal grain boundaries, undergoes colonization. It was shown [31] that even after 35 days from the beginning of exposure, individual colonies of bacteria were found at the metal grain boundaries according to morphological features, Figure $6 a$ (section " $c$ "), and the biofilm significantly changed the metal surface, Figure $6 b$. In fact, not a metal-environment interphase boundary but a complex metal-biofilm-environment system exists.
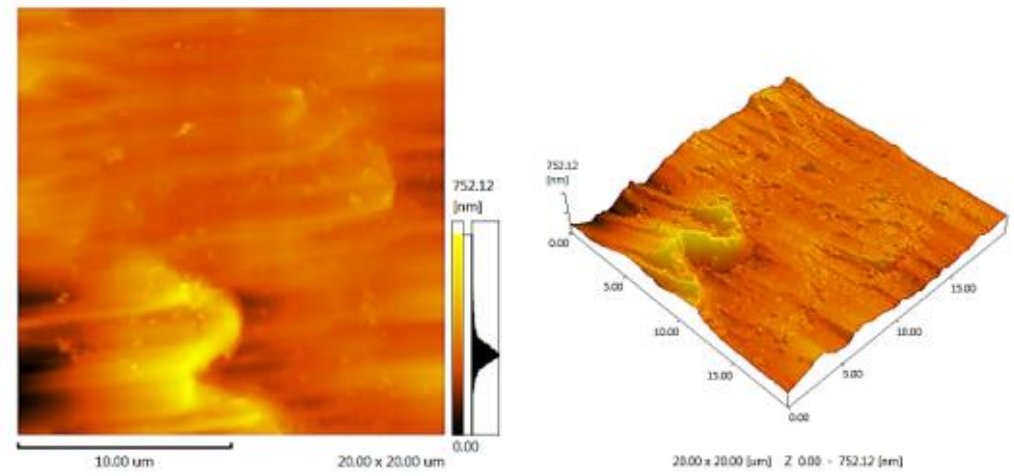

$2000=2000$ land $2005-752.12 \mathrm{lmm}$

$a$
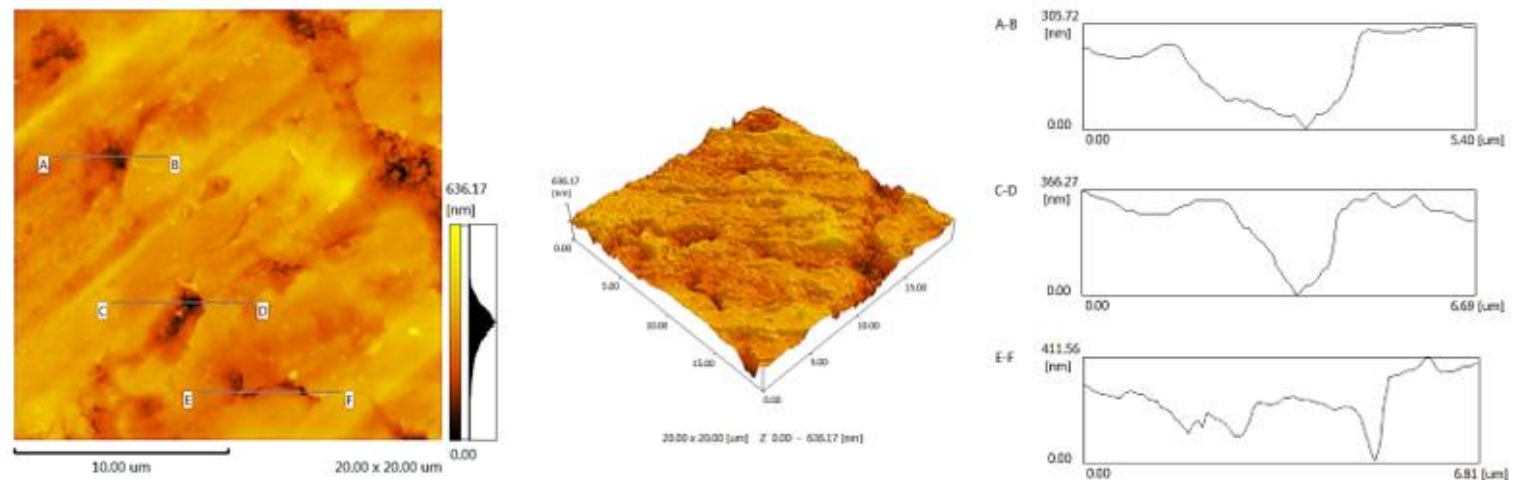

$b$
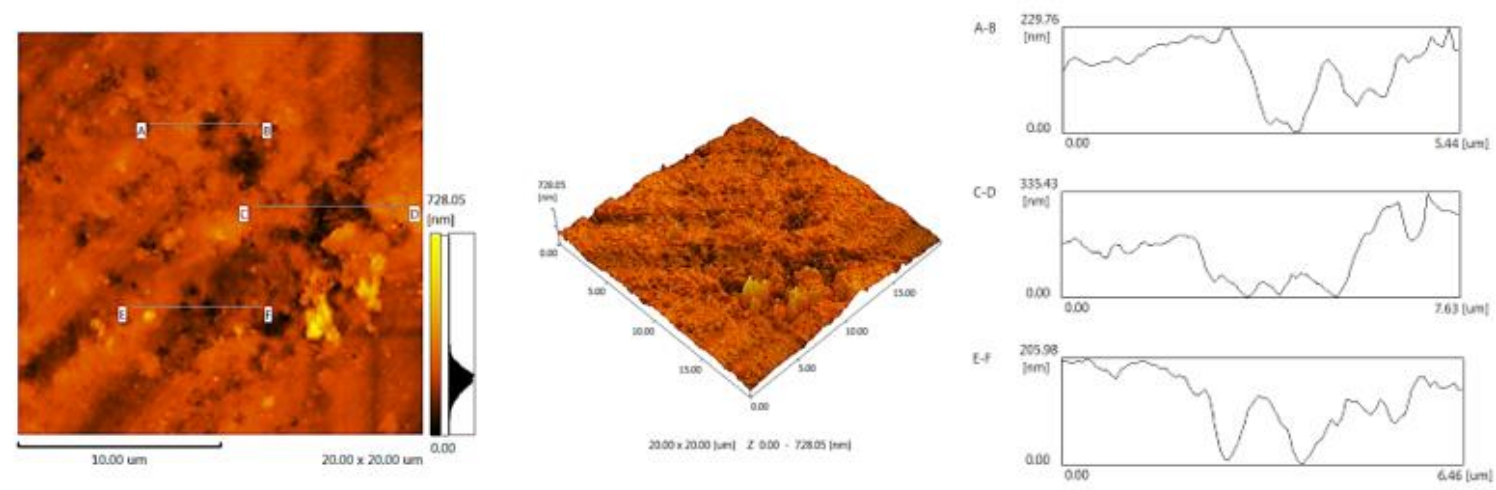

c

Figure 7. AFM image of the surface and surface profile of a low-carbon steel sample: blank sample (a); after exposure to Pseudomonas aeruginosa bacteria for one day $(b)$ or three days (c). 
Thus, depending on the nature of the metal and the type of bacteria, active colonization of the metal surface with formation of a biofilm on it occurs in 1-5 days. The solvation of adhesin compounds that form the basis of the biofilm and the products of the vital activity of bacteria are believed to be the reason for the formation of a liquid exudate on the metal surface [29-33].

This visually observed phenomenon can serve as a kind of a test for the corrosivity of a "metal on dense nutrient medium - microorganism" system without the need for long-term field tests.

Atomic force microscopy (AFM) was used to determine the depth of the metal damage at the stage of surface colonization with bacteria. It should be noted that due to the large and sharp difference in the heights of the topographic structures analyzed, AFM scanning is used quite rarely in studies of this kind [34-38]. The study by Kalinina et al. [39] is among the first works where a steel sample was not in a liquid medium but under metal-atmosphere conditions approximating natural ones. As one can see from Figure 7a, the surface of the blank sample has a homogeneous layered structure with small height variations where the values of $R_{\mathrm{a}}$ and $R_{\mathrm{z}}$ amount to 0.054 and 0.37 microns, respectively. After removal of the biological material, corrosion damage in the form of inhomogeneous depressions formed after exposure to Pseudomonas aeruginosa bacteria for one or three days is clearly observed on steel samples (Figure $7 b, c$ ).

As one can see from Figure $8 a, b$, the ulcerous and pitting nature of steel corrosion due to non-uniform population of the surface at early exposure stages is predominant, although indications of corrosion cracking are found at the metal edges (Figures 8,9).

In the case of zinc, already by the 3-5th day of exposure, almost complete dissolution of the oxide film occurs at the boundary with the biofilm and a sub-grain texture of the nearsurface metal layer becomes visible. The grain boundaries become subject to further colonization by bacteria with intergranular destruction of the metal (Figure 9).

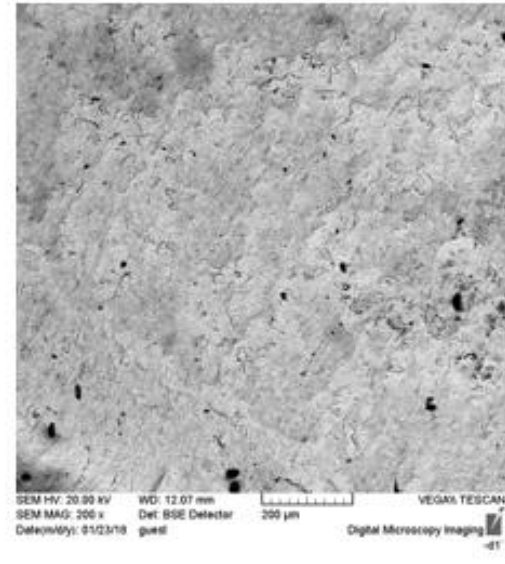

$a$

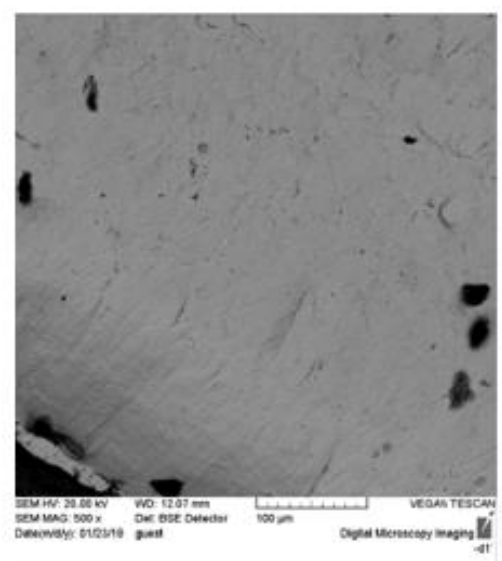

$b$

Figure 8. Steel surface condition after exposure to bacteria for 3 days with signs of pitting corrosion (magnification: $a-\times 200 ; b-\times 500$ ). 


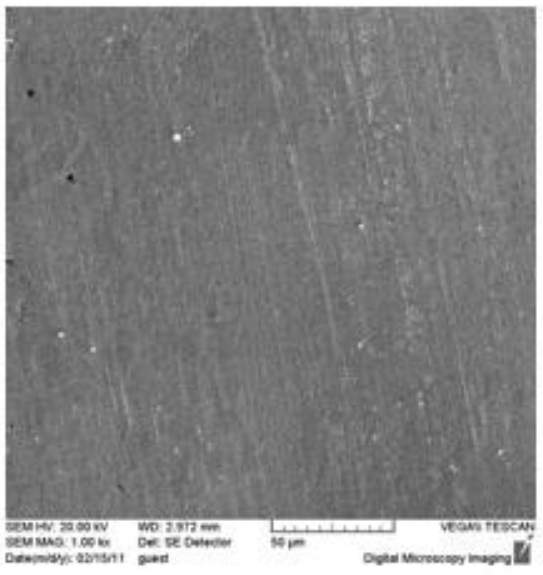

$a$

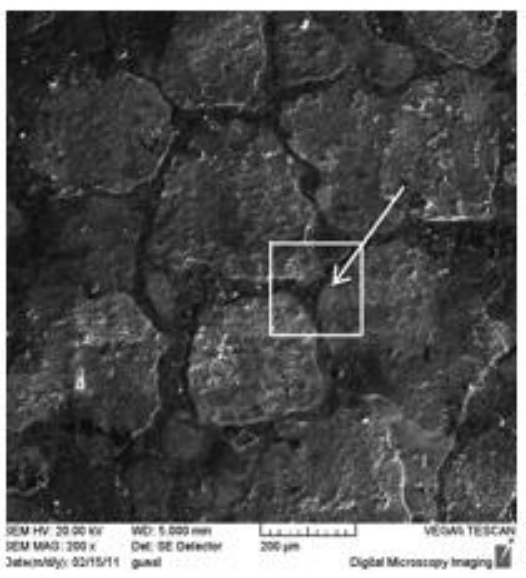

$b$

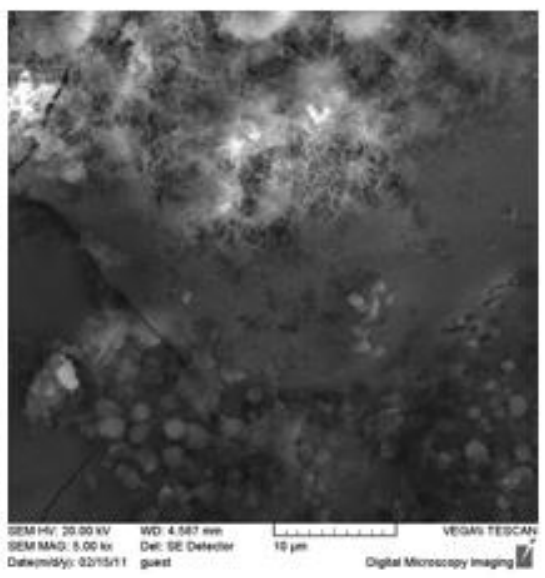

$c$

Figure 9. Micrographs of zinc surface: $a$ - initial surface of zinc that did not contact bacteria $(\times 1000) ; b, c$ - zinc surface after 5 days of exposure upon exposure to Escherichia coli bacteria $(\times 200$ and $\times 5000$, respectively).

On exposure of steel surface to bacteria, the signs of intergranular corrosion appear much later, Figure 10.

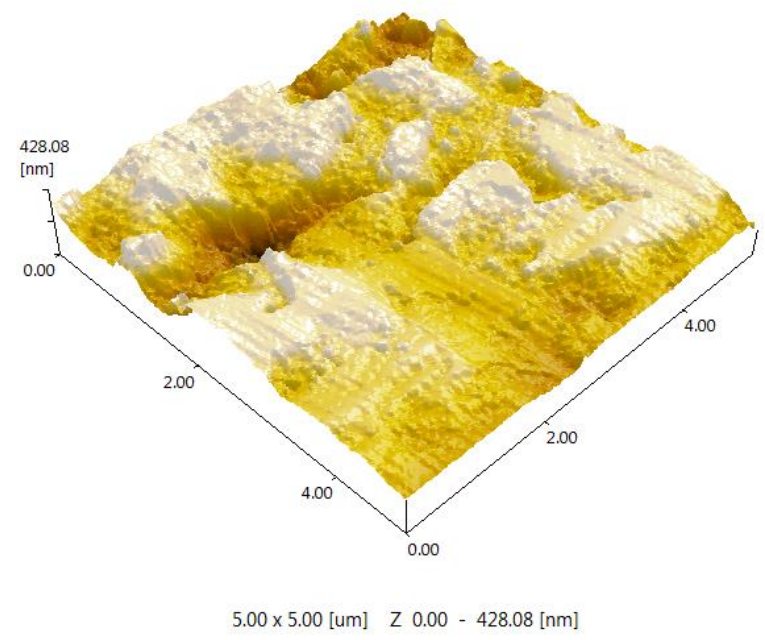

Figure 10. AFM image of the surface of a low-carbon steel sample after exposure to Pseudomonas aeurogenosa bacteria for 10 days.

According to [29-33], the liquid-drop exudate whose formation correlates with the colonization of the metal surface with bacteria allows one to analyze the corrosive components. On the one hand, they are localized at the metal-biofilm interface. On the other hand, they diffuse to the "biofilm-environment" interface and are concentrated in the liquid droplet exudate. It was assumed [29-33] that corrosive substances and their amount in the exudate match those acting on the metal surface. 
Taking into account that the $\mathrm{pH}$ of the exudate at the stage of biological stimulation of corrosion is no smaller than 7 , analysis of the chemical composition of the exudate was carried out by two compounds, i.e., hydrogen peroxide and ammonia [32, 40].

As follows from Figure 11, the concentration of ammonia in the exudate formed upon zinc exposure to corrosive Bacillus subtilis and Clostridium spp. bacteria reaches $\sim 4.8-5.1$ $\mathrm{mmol} / \mathrm{L}$. As it was noted [40], the time of the exudate appearance, its amount and $\mathrm{pH}$ depend not only on the nature of the metal but also on the type of bacteria (Figure 12). For example, on exposure of zinc to Pseudomonas fluorescens, the exudate in an amount sufficient for the analysis is formed only by the 7th day, while the ammonia concentration does not exceed $\sim 2.8 \mathrm{mmol} / \mathrm{L}$. In the case of Pseudomonas aeruginosa, the maximum ammonia content is comparable to that in the case of Bacillus subtilis and Clostriddium spp. bacteria, however, this value is reached later ( 4-5 days) and decreases much more slowly.

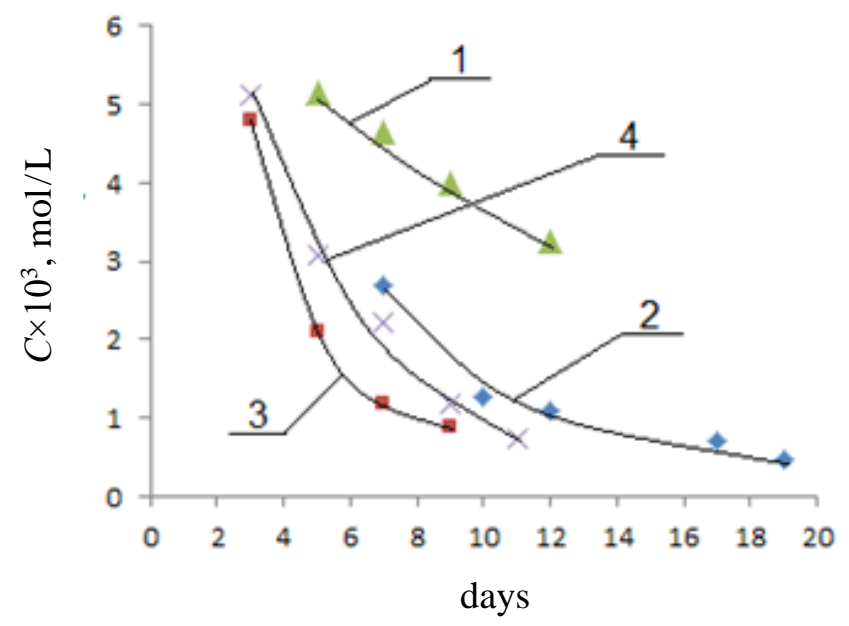

Figure 11. Dependence of ammonia concentration in the exudate on zinc surface on the time of exposure with Pseudomonas aeruginosa (1), Pseudomonas fluorescens (2), Bacillus subtilis (3), Clostridium spp. (4)

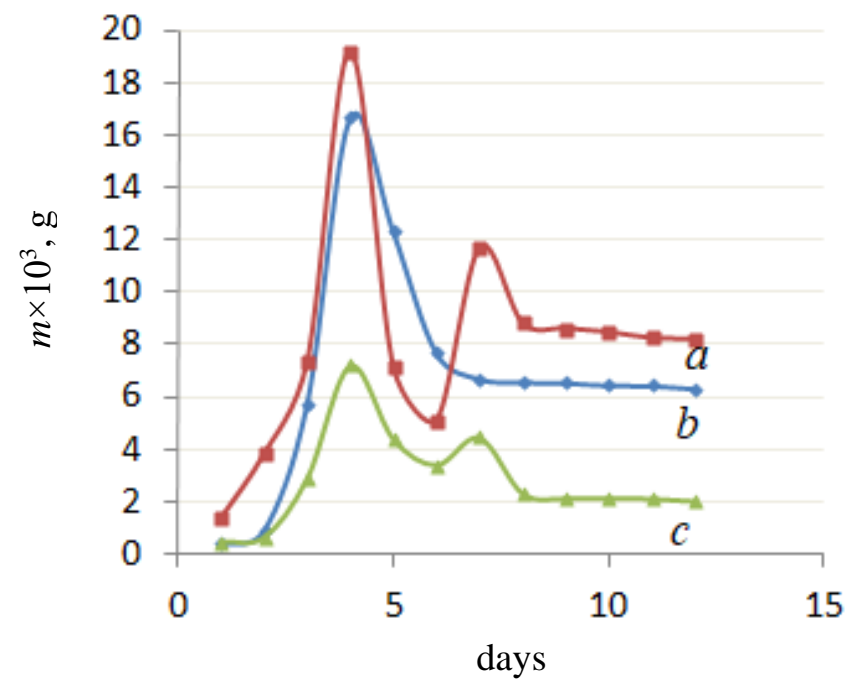

Figure 12. Dependence of exudate accumulation on zinc surface on the time of exposure to bacteria: a - Escherichia coli; b - Staphylococcus aureus; c - Pseudomonas aeruginosa. 
The appearance of ammonia in the exudate results from the biotransformation of the protein of the beef-extract nutrient medium inoculated with bacteria. It should be noted that during the active colonization of the metal surface by bacteria, the $\mathrm{pH}$ of the exudate increases (Figure 13a,b), despite the fact that in the case of most bacteria, the ammonia concentration sharply decreases as the nutrient medium is exhausted.

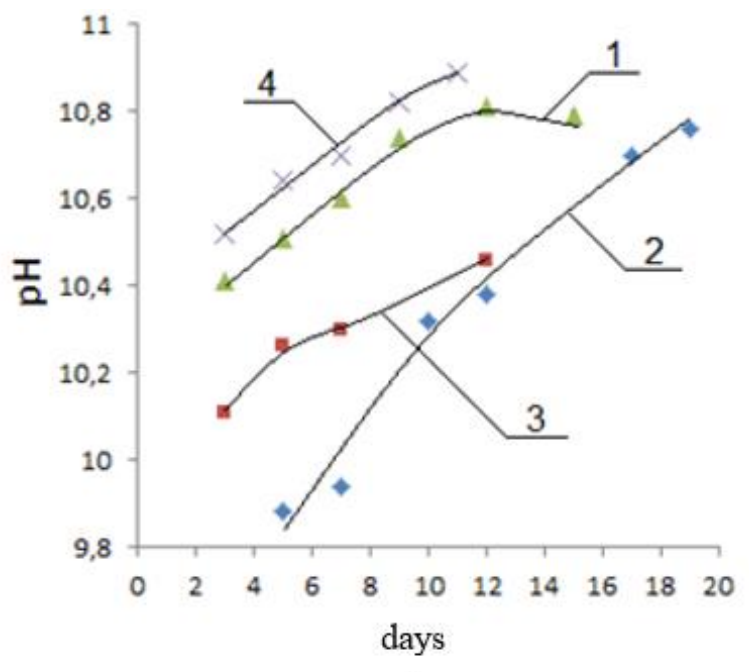

a

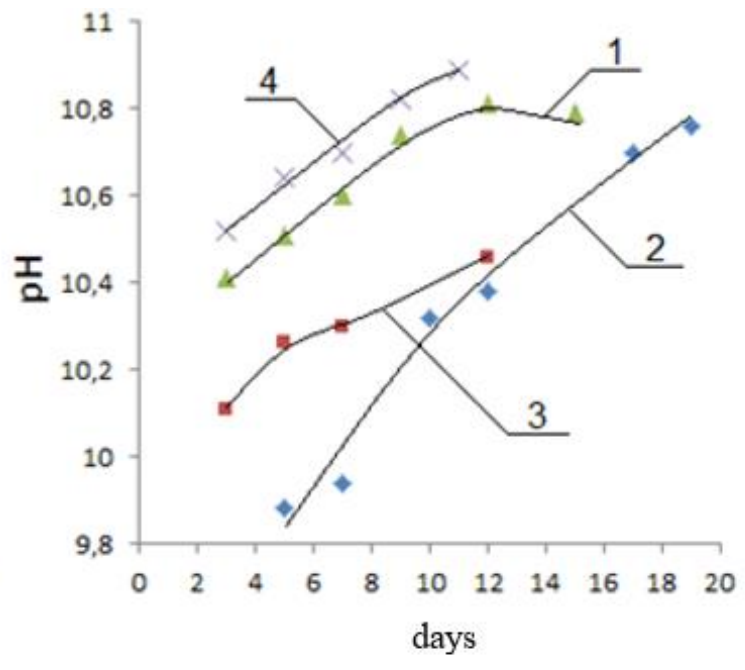

b

Figure 13. Dependence of ammonia concentration in the exudate on zinc surface on the time of exposure with Pseudomonas aeruginosa (1), Pseudomonas fluorescens (2), Bacillus subtilis (3), and Clostridium spp. (4) cultivated on MPA medium (a) and on glucose-mineral medium (b).

Moreover, if bacteria were cultivated on a glucose-mineral medium in the absence of nitrogen as the food source, ammonia was not detected in the exudate but the $\mathrm{pH}$ value increased approximately in the same manner as on the MPA medium (Figure 11b) [32].

It is noteworthy that the plot of $\mathrm{pH}$ on the exposure time will apparently have an extremum that is clearly noticeable in the case of Pseudomonas aeruginosa bacteria [32].

The accumulation of hydrogen peroxide in the exudate on steel surface occurs in a more complex manner. As one can see from Figure 14, the intensity of $\mathrm{H}_{2} \mathrm{O}_{2}$ release into the pericellular environment significantly depends on the type of bacteria. In fact, the maximum concentration of hydrogen peroxide, $\sim 800 \mu \mathrm{mol} / \mathrm{L}$, is achieved in the exudate where zinc is exposed to Pseudomonas aeruginosa bacteria, whereas on exposure to Clostridium spp., this value is almost 10 times smaller.

Hydrogen peroxide is identified in the exudate on zinc surface after 3 days from the beginning of exposure and reaches the maximum concentration after 7 days on average [40].

Of the bacteria studied, only Pseudomonas fluorescens exhibits a relatively low metabolic activity. In fact, the maximum $\mathrm{H}_{2} \mathrm{O}_{2}$ concentration of $350 \mu \mathrm{mol} / \mathrm{L}$ is reached after 12 days of exposure (Figure 14) [40]. 
The dynamics of exudate accumulation on steel surface is less pronounced, therefore, the content of hydrogen peroxide was determined in the exudate during the period of its maximum formation (Figure 15b) [40].

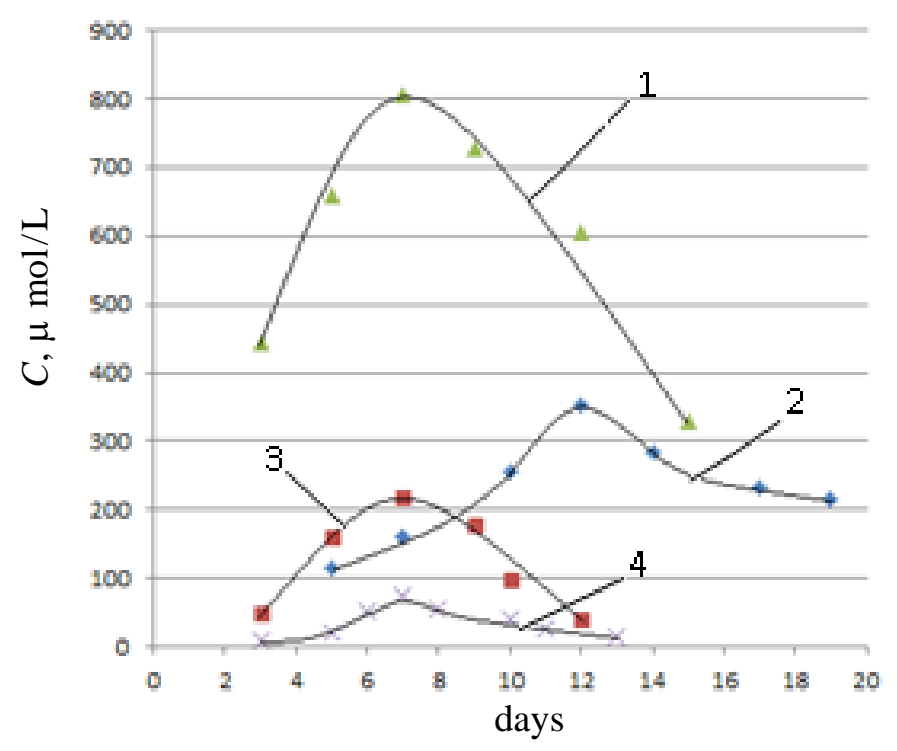

Figure 14. Dependence of $\mathrm{H}_{2} \mathrm{O}_{2}$ concentration in the exudate on zinc surface on the time of exposure with Pseudomonas aeruginosa (1), Pseudomonas fluorescens (2), Bacillus subtilis (3), and Clostridium spp. (4) upon cultivation on MPA.

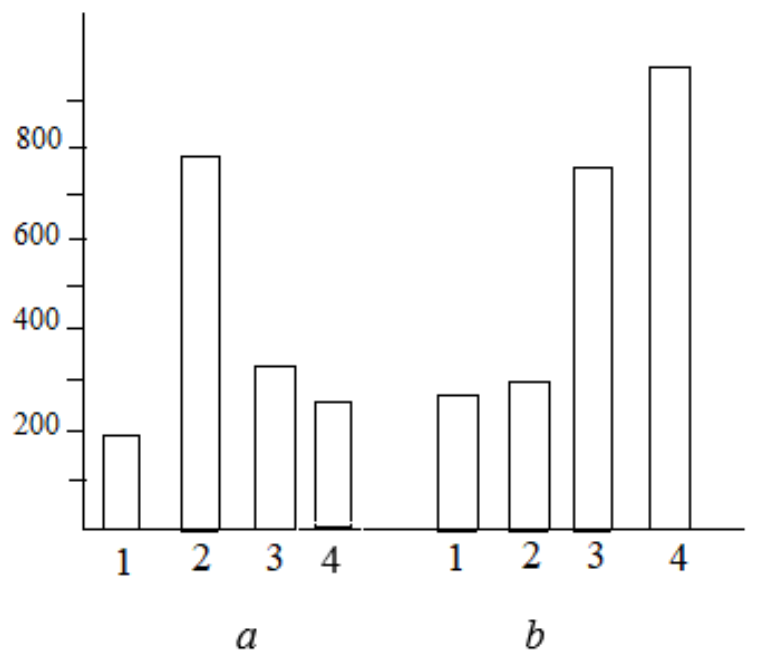

Figure 15. Maximum concentration of hydrogen peroxide $(\mu \mathrm{mol} / \mathrm{L})$ in the exudate on the surface of zinc (a) and steel (b): 1 - Bacillus subtilis; 2 - Pseudomonas aeruginosa; 3 Pseudomonas fluorescens; 4 - Escherichia coli.

For comparison, Figure 15 shows the maximum concentrations of $\mathrm{H}_{2} \mathrm{O}_{2}$ in the exudate on zinc surface as a histogram. The data presented above again confirm that the corrosivity of organotrophic bacteria should be considered only in combination with a particular metal. 
In fact, the concentration of $\mathrm{H}_{2} \mathrm{O}_{2}$ in the exudate on zinc surface exposed to Pseudomonas aeruginosa can reach $\sim 800 \mu \mathrm{mol} / \mathrm{L}$, as well as $c a .300 \mu \mathrm{mol} / \mathrm{L}$ on steel surface.

The data on $\mathrm{H}_{2} \mathrm{O}_{2}$ determination in the exudate on steel surface confirm and develop the concept [29-32], according to which the products of oxygen biotransformation, $\mathrm{H}_{2} \mathrm{O}_{2}$ in particular, by the electron transport system constitute the main stimulating factor of metal corrosion by organotrophic bacteria [29-33, 39-41].

It is known that the superoxide anion $\mathrm{O}_{2}^{-}$is one of the sources of $\mathrm{H}_{2} \mathrm{O}_{2}$ formation in a cell $[18,42,43]$ :

$$
\begin{gathered}
\mathrm{O}_{2}^{-}+\mathrm{H}^{+} \rightarrow{ }^{\cdot} \mathrm{OOH} ; \\
\cdot \mathrm{OOH}+{ }^{\cdot} \mathrm{OOH} \rightarrow \mathrm{H}_{2} \mathrm{O}_{2}+\mathrm{O}_{2} ; \\
\mathrm{O}_{2}^{-}+{ }^{\cdot} \mathrm{OOH}+\mathrm{H}_{2} \mathrm{O} \rightarrow \mathrm{H}_{2} \mathrm{O}_{2}+\mathrm{O}_{2}+\mathrm{OH}^{-} .
\end{gathered}
$$

As one can see from equations (1)-(3), the reactions involving $\mathrm{O}_{2}^{-}$and its protonated form ' $\mathrm{OOH}$ produce $\mathrm{H}_{2} \mathrm{O}_{2}$ and the $\mathrm{OH}^{-}$anion, and $\mathrm{O}_{2}$ is released. In turn, the superoxide ion results from the accidental "leakage" of one electron from the electron transport system of bacteria to $\mathrm{O}_{2}[43]$ :

$$
\mathrm{O}_{2}+\mathrm{e} \rightarrow \mathrm{O}_{2}^{-} .
$$

In addition to reactions (1)-(3), an enzymatic system (superoxide dismutase) that neutralizes the excess amounts of $\mathrm{O}_{2}^{-}$is triggered in the cell:

$$
\mathrm{O}_{2}^{-}+2 \mathrm{H}^{+} \rightarrow \mathrm{H}_{2} \mathrm{O}_{2} .
$$

Thus, the accumulation of $\mathrm{H}_{2} \mathrm{O}_{2}$ and $\mathrm{pH}$ values above 7 result from natural cell processes with participation of $\mathrm{O}_{2}$ that can be enhanced by additional oxygen regeneration by reactions (2) and (3).

At the same time, $\mathrm{H}_{2} \mathrm{O}_{2}$ is corrosive toward metals. In fact, after destruction of the oxide film with participation of biofilm metabolites including $\mathrm{H}_{2} \mathrm{O}_{2}, \mathrm{OH}^{-}$, and $\mathrm{O}_{2}^{-}$, hydrogen peroxide can manifest oxidizing properties toward iron:

$$
\begin{aligned}
\mathrm{Fe}-2 \mathrm{e} & \rightarrow \mathrm{Fe}^{2+}, \\
\mathrm{H}_{2} \mathrm{O}_{2}+2 \mathrm{e} & \rightarrow 2 \mathrm{OH}^{-}, \\
\mathrm{Fe}^{2+}+2 \mathrm{OH}^{-} & \rightarrow \mathrm{Fe}(\mathrm{OH})_{2} .
\end{aligned}
$$

Moreover, the $\mathrm{Fe}^{2+}$ ion is an efficient catalyst for the decomposition of hydrogen peroxide by the general equation:

$$
2 \mathrm{H}_{2} \mathrm{O}_{2} \rightarrow 2 \mathrm{H}_{2} \mathrm{O}+\mathrm{O}_{2} \text {. }
$$


Catalase that decomposes hydrogen peroxide more actively than in the case of $\mathrm{Fe}^{2+}$ catalysis was qualitatively found in the exudate. The mechanism of the biocatalytic decomposition of $\mathrm{H}_{2} \mathrm{O}_{2}$ has been well studied [44]:

$$
\begin{gathered}
\mathrm{H}_{2} \mathrm{O}_{2}+\mathrm{Fe}^{2+} \rightarrow \mathrm{Fe}^{3+}+\mathrm{OH}^{-}+{ }^{\circ} \mathrm{OH} \\
\mathrm{OH}+\mathrm{H}_{2} \mathrm{O}_{2} \rightarrow \mathrm{H}_{2} \mathrm{O}+{ }^{\cdot} \mathrm{OOH}, \\
\mathrm{OOH}_{2} \rightleftarrows \mathrm{O}_{2}^{\cdot-}+\mathrm{H}^{+} \\
\mathrm{O}_{2}^{\cdot-}+\mathrm{H}_{2} \mathrm{O}_{2} \rightarrow \mathrm{O}_{2}+{ }^{-} \mathrm{OH}+{ }^{\circ} \mathrm{OH}, \\
\mathrm{Fe}^{3+}+\mathrm{O}_{2}^{\cdot-} \rightarrow \mathrm{Fe}^{2+}+\mathrm{O}_{2} .
\end{gathered}
$$

According to [31-33], the additional formation of $\mathrm{O}_{2}$ in the zone where bacteria contact with the metal accelerates the corrosion of steel and the formation of $\mathrm{Fe}(\mathrm{OH})_{3}$ by the overall reaction:

$$
4 \mathrm{Fe}(\mathrm{OH})_{2}+\mathrm{O}_{2}+2 \mathrm{H}_{2} \mathrm{O} \rightarrow 4 \mathrm{Fe}(\mathrm{OH})_{3} \text {. }
$$

The composition of the so-called rust, $\mathrm{Fe}(\mathrm{OH})_{3}$, can be variable: $n \mathrm{Fe}(\mathrm{OH})_{2} \cdot m \mathrm{Fe}(\mathrm{OH})_{3} \cdot q \mathrm{H}_{2} \mathrm{O}$.

On exposure of zinc to organotrophic bacteria, hydrogen peroxide can react with the metal by similar reactions [44]:

$$
\begin{gathered}
\mathrm{Zn}-2 \mathrm{e}=\mathrm{Zn}^{2+} \\
\mathrm{H}_{2} \mathrm{O}_{2}+2 \mathrm{e}=2 \mathrm{OH}^{-}
\end{gathered}
$$

or in total,

$$
\mathrm{Zn}+\mathrm{H}_{2} \mathrm{O}_{2}=\mathrm{Zn}(\mathrm{OH})_{2} \text {. }
$$

The ability of hydrogen peroxide to stimulate the corrosion process at low concentrations was shown in a model system [45].

The process of zinc corrosion in an exudate saturated with atmospheric oxygen and with oxygen formed in reactions (2) and (3) can also occur by an electrochemical mechanism with oxygen depolarization accompanied by accumulation of zinc on the surface of $\mathrm{Zn}(\mathrm{OH})_{2}$ :

$$
\begin{gathered}
\mathrm{Zn}-2 \mathrm{e}=\mathrm{Zn}^{2+} \\
\mathrm{O}_{2}+2 \mathrm{H}_{2} \mathrm{O}+4 \mathrm{e}=4 \mathrm{OH}^{-}
\end{gathered}
$$

or in total,

$$
2 \mathrm{Zn}+\mathrm{O}_{2}+2 \mathrm{H}_{2} \mathrm{O}=2 \mathrm{Zn}(\mathrm{OH})_{2} .
$$

In addition to hydrogen peroxide, ammonia plays an important role in the biocorrosion of zinc [45].

According to [45], on prolonged exposure at high $\mathrm{pH}$, ammonia at high concentrations converts $\mathrm{Zn}(\mathrm{OH})_{2}$ to water-soluble complex compounds: 


$$
\begin{gathered}
\mathrm{Zn}(\mathrm{OH})_{2}+2 \mathrm{OH}_{\text {sol }}^{-} \rightarrow\left[\mathrm{Zn}(\mathrm{OH})_{4}\right]_{\text {sol }}^{2-} \\
\mathrm{Zn}(\mathrm{OH})_{2}+4 \mathrm{NH}_{3 \text { sol }} \rightarrow\left[\mathrm{Zn}\left(\mathrm{NH}_{3}\right)_{4}\right](\mathrm{OH})_{2 \text { sol }}
\end{gathered}
$$

The transition of these complexes to the exudate enhances the corrosion process by shifting the equilibrium towards the formation of $\mathrm{Zn}(\mathrm{OH})_{2}$.

Ammonia released by organotrophic bacteria can also play the role of a buffer that favors maintaining the $\mathrm{pH}$ at a sufficiently high level for a long time [45].

Thus, the results of studies performed in the past decade concerning the corrosion of metals on exposure to organotrophic bacteria cultivated on a dense nutrient medium made it possible to conclude unambiguously that the products of intracellular biotransformation of oxygen play the predominant role in stimulating the metal degradation.

\section{References}

1. G.F. Hays, Now is the time, Adv. Mater. Res., 2010, 95, 1-2.

2. J.W. Young, The bacterial reduction of sulphates, Can. J. Res., 1936, 14, 49-54.

3. D.M. Updegraff, Microbiological corrosion of iron and steel, Corrosion, 1955, 11, no. 10, 44-48. doi: 10.5006/0010-9312-11.10.44

4. H.A. Videla, Manual of Biocorrosion, 1996, CRC Press, USA, 304 p.

5. A.A. Gerasimenko and T.A. Andryushchenko, Comparative resistance of materials and coatings on pressure sensors under tropical conditions against microbial corrosion, Tekhnol. Mashinostr., 2010, no. 11, 54-57 (in Russian).

6. N. Kip and J. van Veen, The dual role of microbes in corrosion, ISME J., 2015, 9, 542551. doi: $10.1038 /$ ismej.2014.169

7. R.K. Thauer, K. Jungermann and K. Decker, Energy Conservation in Chemotrophic Anaerobic Bacteria, Bacteriol. Rev., 1977, 41, no. 1, 100-180.

8. S.W. Borenstein, Microbiologically Influenced Corrosion Handbook, 1994, ISBN 185573-127-4, Woodhead Publishing Ltd., Cambridge, 288 p.

9. R. Javaherdashti, Microbiologically Influenced Corrosion an Engineering Insight, 2008, Springer-Verlag, UK, $164 \mathrm{p}$.

10. K.L. Keller and J.D. Wall, Genetics and molecular biology of the electron flow for sulfate respiration in Desulfovibrio, Front. Microbiol., 2011, 2, Article 135, 1-17. doi: $10.3389 /$ fmicb.2011.00135

11. M.R. Hyman, S.A. Russel, R.L. Ely, K.J. Williamson and D.J. Arp, Inhibition, Inactivation, and Recovery of Ammonia-Oxidizing Activity in Cometabolism of Trichloroethylene by Nitrosomonas europaea, Appl. Environ. Microbiol., 1995, 61, no. 4, 1480-1487. doi: 10.1128/AEM.61.4.1480-1487.1995

12. A.K. Lee and D.K. Newman, Microbial iron respiration: impacts on corrosion processes, Appl. Microbiol. Biotechnol., 2003, 62, 134-139. doi: 10.1007/s00253-003-1314-7 
13. D. Emerson, E.J. Fleming and J.M. McBeth, Iron-oxidizing bacteria: an environmental and genomic perspective, Аnnu. Rev. Microbiol., 2010, 63, 561-583. doi: 10.1146/annurev.micro.112408.134208

14. A.A. Gerasimenko, Protection from corrosion, aging and biodegradation of vehicles, equipment and structures, Reference book in 2 volumes, 1987, Moscow, Mashinostroenie, 784 pp. (in Russian).

15. W.P. Iverson, Biological corrosion, Adv. Corros. Sci. Technol., 1972, 42 p.

16. J.G. Stoecker, Microbiologically Influenced Corrosion, 2001, 2, ISBN 1-57590-113-7, NACE International, USA, $246 \mathrm{p}$.

17. E. Cabiscol, J. Tamarit and J. Ros, Oxidative stress in bacteria and protein damage by reactive oxygen species, Int. Microbiol., 2000, 3, 3-8.

18. F. Auchere and F. Rusnak, What is the ultimate fate of superoxide anion in vivo?, J. Biol. Inorg. Chem., 2002, 7, 664-667. doi: 10.1007/s00775-002-0362-2

19. O.K. Nepryakhina, A.Yu. Kuznetsova, V.P. Skulachev, K.G. Lyamzaev, D.S. Izyumov, O.Yu. Pletjushkina and B.V. Chernyak, Reactive oxygen species generated in mitochondria induce fragmentation of the mitochondrial reticulum in HeLa cells, Dokl. Biol. Sci., 2008, 420, 221-223. doi: 10.1134/S0012496608030241

20. M.V. Chelnokova, D.V. Belov, T.N. Sokolova, V.F. Smirnov, A.A. Kalinina and V.R. Kartashov, Generation of superoxide anion radical by micromycetes and its role in metal corrosion, Izv. Vyssh. Uchebn. Zaved., Khim. Khim. Tekhnol., 2011, 54, no. 10, 133-136 (in Russian).

21. J.P. Busalmen, M. Vazquez and S.R. de Sanchez, New evidences on the catalase mechanism of microbial corrosion, Electrochim. Acta, 2002, 47, 1857-1865. doi: 10.1016/S0013-4686(01)00899-4

22. A.A. Gerasimenko and T.A. Andryushchenko, Copper protection from microbial corrosion in marine and seaside environments, Tekhnol. Mashinostr., 2013, no. 1, 3944 (in Russian).

23. V.A. Karpov, Yu.L. Koval'chuk, Yu.I. Kuznetsov, I.A. Beleneva and U.V. Kharchenko, Protection of steels from seawater corrosion in closed spaces, Korroz.: Mater., Zashch. (Corrosion: materials, protection), 2013, no. 5, 35-40 (in Russian).

24. Y.-J. Chang, C.-H. Hung, J.W. Lee, Y.-T. Chang, F.-Y. Lin and C.-J. Chuang, A study of microbial population dynamics associated with corrosion rates influenced by corrosion control materials, Int. Biodeterior. Biodegrad., 2015, no. 102, 330-338. doi: 10.1016/j.ibiod.2015.03.008

25. G. Lear, Microbial Biofilms: Current Research and Applications, 2012, Caister Academic Press, Wymondham, 228 p.

26. G. Schaule, T. Griebe and H.-C. Flemming, Steps in biofilm sampling and characterization in biofouling cases, Microbiologically Influenced Corrosion of Industrial Materials, 1999, 157, no. 1, 117-138. 
27. V.F. Smirnov， T.N. Sokolova, D.V. Belov, O.V. Kuzina and V.R. Kartashov, Microbiological corrosion of aluminum alloys, Appl. Biochem. Microbiol., 2008, 44, no. 2, 192-196.

28. M.V. Chelnokova, D.V. Belov, T.N. Sokolova, V.F. Smirnov, A.A. Kalinina and V.R. Kartashov, Generatsiya superoksidnogo anion-radikala mikromitsetami i ego rol' v korrozii metallov, Izv. Vyssh. Uchebn. Zaved., Khim. Khim. Tekhnol., 2011, 54, no. 10, 133-136 (in Russian).

29. M.V. Chelnokova, D.V. Belov, A.A. Kalinina, T.N. Sokolova, V.F. Smirnov and V.R. Kartashov, Aktivnye formy kisloroda v korrozii metallov, Korroz.: Mater., Zashch. (Corrosion: materials, protection), 2011, no. 3, 19-26 (in Russian).

30. S.Yu. Radostin, A.A. Moskvichev, M.V. Chelnokova, A.A. Kalinina, T.N. Sokolova, V.V. Isaev, A.N. Moskvichev, E.N. Razov and V.R. Kartashov, O nachal'nom etape korrozii otsinkovannoi stali pod vozdeistviem bakterii Escherichia coli 321-5, Korroz.: Mater., Zashch. (Corrosion: materials, protection), 2013, no. 11, $43-48$ (in Russian).

31. A.A. Kalinina, E.N. Razov, N.V. Gurskii, A.S. Makedoshin, T.N. Sokolova, E.P. Komova and O.V. Kuzina, Mikrostrukturnoe issledovanie stimuliruyushchei roli bakterii pseudomonas aeruginosa v korrozii nizkouglerodistoi stali, Korroz.: Mater., Zashch. (Corrosion: materials, protection), 2019, no. 4, 40 (in Russian).

32. S.Yu. Radostin, A.A. Kalinina, T.N. Sokolova, V.R. Kartashov, E.N. Razov and V.F. Smirnov, Vliyanie pitatel'noi sredy na khimicheskii sostav korrozionno-aktivnykh ekzometabolitov bakterii Bacillus subtilis, vozdeistvuyushchei na poverkhnost' tsinka, Korroz.: Mater., Zashch. (Corrosion: materials, protection), 2017, № 4. 42-47 (in Russian).

33. A.A. Kalinina, V.V. Isaev, T.N. Sokolova and V.I. Naumov, Effect of corrosive metabolites produced by Escherichia Coli bacteria on zinc corrosion, Korroz.: Mater., Zashch. (Corrosion: materials, protection), 2019, no. 5, 42-47 (in Russian).

34. S.J. Yuan and S.O. Pehkonen, AFM study of microbial colonization and its deleterious effect on 304 stainless steel by Pseudomonas NCIMB 2021 and Desulfovibrio desulfuricans in simulated seawater, Corros. Sci., 2009, 51, 1372-1385. doi: 10.1016/j.corsci.2009.03.037

35. S. Maruthamuthu, P. Dhandapani, S. Ponmariappan, J.-H. Bae, N. Palaniswamy and P.K.S.M. Rahman, Impact of Ammonia Producing Bacillus sp. on Corrosion of Cupronickel alloy 90:10, Met. Mater. Int., 2009, 15, no. 3, 409-419. doi: 10.1007/s12540-009-0409-9

36. L.-C. Xu, H.H.P. Fang and K.Y. Chan, Atomic Force Microscopy Study of Microbiologically Influenced Corrosion of Mild Steel, J. Electrochem. Soc., 1999, 146, no. 12, 4455-4460. doi: 10.1149/1.1392658

37. S.J. Yuan and S.O. Pehkonen, Microbiologically influenced corrosion of 304 stainless steel by aerobic Pseudomonas NCIMB 2021 bacteria: AFM and XPS study, Colloids Surf., B, 2007, 59, 87-99. doi: 10.1016/j.colsurfb.2007.04.020 
38. I.B. Beech, J.R. Smith, A.A. Steele, I. Penegar and S.A. Campbell, The use of atomic force microscopy for studying interactions of bacterial biofilms with surfaces, Colloids Surf., B, 2002, 23, 231-247. doi: 10.1016/S0927-7765(01)00233-8

39. A.S. Makedoshin, A.A. Kalinina, T.S. Sazanova, V.M. Vorotyntsev and T.N. Sokolova, Mikrostrukturnoe issledovanie mikrobiologicheskoi korrozii nizkouglerodistoi stali pod vozdeistviem bakterii Pseudomonas aeurogenosa, Korroz.: Mater., Zashch. (Corrosion: materials, protection), 2018, № 6. 35-48 (in Russian).

40. A.A. Kalinina, S.Yu. Radostin, S.Yu. Khlopin, T.N. Sokolova, A.N. Moskvichev, E.N. Razov and V.R. Kartashov, Rol' aktivnykh form kisloroda kak ekzometabolitov bakterii-organotrofov $\mathrm{v}$ initsiirovanii korrozii tsinka, Korroz.: Mater., Zashch. (Corrosion: materials, protection), 2014, no. 3, 44-47 (in Russian).

41. A.A. Kalinina, S.Yu. Radostin, S.Yu. Chloponin, A.N. Moskvichev, E.N. Razov, T.N. Sokolova and V.R. Kartashov, The effect of reactive oxygen intermediates, exometabolites of organotrophic bacteria, on initiation of zinc corrosion, Prot. Met. Phys. Chem. Surf., 2016, 52, no. 7, 1223-1226. doi: 10.1134/S207020511607008X

42. B.H.J. Bielski, D.E. Cabelli, R.L. Arudi and A.B. Ross, Reactivity of $\mathrm{HO}_{2} / \mathrm{O}_{2}^{-}$Radicals in Aqueous Solution, J. Phys. Chem. Ref. Data, 1985, 14, no. 4, 1041-1100. doi: $10.1063 / 1.555739$

43. D.T. Sawyer and M.J. Gibian, The chemistry of superoxide, Tetrahedron, 1979, 35, 1471-1481. doi: $10.1016 / 0040-4020(79) 80032-0$

44. H.J. Fenton, Oxidation of tartaric acid in the presence of iron, J. Chem. Soc., 1984, 65, 899-910. doi: $\underline{\text { 10.1039/CT8946500899 }}$

45. A.A. Kalinina, S.Yu. Radostin, A.S. Makedoshin, T.N. Sokolova, V.F. Smirnov and V.R. Kartashov, Modelirovanie uslovii biotransformatsii kisloroda bakteriyamiorganotrofami v peroksid vodoroda, stimuliruyushchii korroziyu tsinka, Izv. VUZov, Prikl. Khim. Biotekhnol., 2017, 7, no. 2, 80-88 (in Russian). 